\title{
The Influence of Drying Temperature on Selected Properties of Flour Produced from Orange Fleshed Sweet Potato Tubers
}

\author{
Haruna, S.A. (1) \\ Food \& Strategic Reserve Department, \\ Federal Ministry of Agriculture and Rural Development \\ Abuja, Nigeria. \\ Chinma, C. E. (3) \\ Department of Food Science and Technology, Federal \\ University of Technology \\ Minna, Nigeria.
}

\author{
Adejumo, B. A. (2) \\ Department of Agricultural and Bioresources Engineering, \\ Federal University of Technology, \\ Minna, Nigeria. \\ Akanya, H. O. ${ }^{(4)}$ \\ Department of Biochemistry, Federal University of \\ Technology \\ Minna, Nigeria.
}

Okolo, C. A. ${ }^{(5)}$

Food Reserve \&Storage Department

Federal Ministry of Agriculture and Rural Development , Abuja Nigeria.

\begin{abstract}
The effect of drying temperature on some nutritional properties of flour from orange flesh sweet potato was investigated with the view to produce high quality flour. About One Kilogram (1kg) of orange flesh sweet potatoes was for this research work. The fresh unpeeled orange flesh sweet potato tubers were washed thoroughly, drained, peeled and sliced into $0.5 \mathrm{~mm}$ slice thickness. With the initial properties of the fresh orange flesh sweet potato determined, the sliced potato was soaked in $2.5 \%$ Sodium Metabisulphate for 30 minutes. The pretreated potato slices were then drained and divided into samples $A$, B, C, D and E respectively of One hundred and Fifty grams (150g) each. The samples $A, B, C, D$ and $E$ were dried in hot air oven set at $40^{\circ} \mathrm{C}, 45^{\circ} \mathrm{C}, 50^{\circ} \mathrm{C}, 55^{\circ} \mathrm{C}$, and $60^{\circ} \mathrm{C}$ respectively until constant weights were obtained at three consecutive reading. The cooled dried slices were crushed and milled (cyclone mill) into flour. The milled flour was sieved using a 75um (micron meter) to obtain fine flour of uniform particle size. The nutritional properties of the flour were determined using standard methods. Data collected were analyzed using SPSS (15.0) and the means separated. The results showed that generally, drying decreases the moisture, fat, crude fiber, protein, vitamin $\mathrm{C}$ and beta carotene contents of fresh orange flesh sweet potato tubers while drying increases the ash and carbohydrate contents irrespective of the drying temperature. The drying temperature of $45^{\circ} \mathrm{C}$ is recommended for drying fresh orange flesh sweet potato tuber to obtain high quality flour in terms of lower moisture content $(4.9 \%)$ and higher protein (3.51\%), vitamin C (10.1 $\mathrm{mg} / 100 \mathrm{~g})$ and beta carotene $(289.8 \mathrm{mg} / 100 \mathrm{~g})$.
\end{abstract}

Keywords: Orange flesh sweet potato, Beta carotene, protein, water absorption capacity

\section{INTRODUCTION}

Sweet potato (Ipomoea batatas) is one of the world most important food crops and an important staple in Nigeria and other developing countries [1] [2]. It is a low input crop used as vegetable, desert, source of starch and animal feed [3]. In Nigeria, sweet potato is mostly consumed as a snack, roasted, boiled, used with fresh yams in pounded yam and as a sweetener in beverage production [4]. It contains carbohydrates, beta-carotene (pro-vitamin A), vitamin C, vitamin $\mathrm{B}_{6}$, minerals such as calcium, phosphorus, iron, potassium, magnesium and zinc [3] [4] [5]. On a fresh weight basis, Mexican varieties of sweet potato provided $103 \mathrm{kcal} / 100 \mathrm{~g}$ of energy, and had 24\% carbohydrates, $2.9 \%$ fibre, $23 \mathrm{mg} / 100 \mathrm{~g}$ vitamin $\mathrm{C}$ and $204 \mathrm{mg} / 100 \mathrm{~g}$ potassium. Sweet potato is low in fat (1-3\% dry weight) and although low in protein content (3-5\% dry weight), value is near that of casein [5] [6].

The annual production of all variety of sweet potatoes in Nigeria is estimated at 843,000 metric tonnes in 2007 with a percentage loss of about 35\% [2] [7]. Sweet potatoes are highly perishable in nature irrespective of the variety, which often results to high amount of losses annually, due to its non-diversity and limited use [9] [6]. It is generally recognized as an economically underutilized nutritious food despite its health benefits, especially the orange flesh sweet potato (OFSP) [6] [5] [10]. Generally in Sub Saharan Africa, the sweet potato family including orange flesh sweet potato (OFSP) has a weak value chain characterized by limited storability, poor marketing capacity, and little investment in the post harvest business/ activities [11] [9].

Orange flesh sweet potato (OFSP) (Ipomoea batatas $(L)$ is a variety of sweet potato characterized by its orange or yellow coloured tubers (Plate 1). Presently, it is strongly emerging as the most popular commonly cultivated and demanded variety, due to its unique properties. It is rich in vitamin A and beta carotene (a carotenoid plant pigment responsible for the yellow colouration) [7] [9]. It is an important staple for the poor and less privileged considering its relative ease of cultivation, and poor utilization and numerous health benefits, for children and pregnant women who desired these nutrients [12] [13]. The orange flesh sweet potato (OFSP) may contain up to $4,000 \mu / \mathrm{mg}$ fresh weight basis of beta carotene [6]. The carotenoids content of OFSP has been found to range from 0 to $20>20 \mathrm{mg} / 100 \mathrm{~g}$ of fresh weight, 
which would be equivalent to $060 \mathrm{mg} / 100 \mathrm{~g}$ weight [12]. It is likely that cultivars with medium to high levels colours contain most of their carotenoids in form of beta carotene [11] [12].

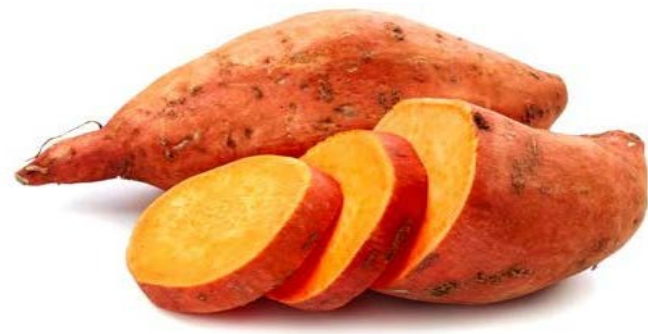

Plate 1. Orange flesh sweet potato tuber

Orange flesh sweet potato tubers can be processed into flour which is less bulky and more stable than the highly perishable fresh root thereby reducing losses. Drying of fresh orange flesh sweet potato tubers into flour at the appropriate drying temperature will solve the problem of discoloration and enhance the production of high quality orange flesh sweet potato flour [13] [14] .

The Orange flesh sweet potato flour can be used as thickener in soup, bakery products and as substitute for cereal flours [13] [15]. The use of orange flesh sweet potato flour can enhance food product through colour, flavor, natural sweetener and supplemented nutrients. The common method of drying to allow massive and rapid processing of fresh to dried products is the hot air drying [15] [14]. However, hot air drying greatly affects the sensory and nutritional characteristics of end products [16] [17] [18]. There is the need to be investigated the effect of drying temperature on the nutritional properties of orange flesh sweet potato tuber slices with a view to produce high quality flour.

\section{MATERIALS AND METHODS}

About One Kilogram (1kg) of orange flesh sweet potatoes was for this study. The fresh unpeeled orange flesh sweet potato tubers were washed thoroughly, drained, peeled and sliced into $0.5 \mathrm{~mm}$ slice thickness. With the initial properties of the fresh orange flesh sweet potato determined, the sliced potato was soaked in $2.5 \%$ Sodium Metabisulphate for 30 minutes. The pretreated potato slices were then drained and divided into samples A, B, C, D and E respectively of One hundred and Fifty grams (150g) each. The samples A, B, C, $\mathrm{D}$ and $\mathrm{E}$ were dried in hot air oven set at $40^{\circ} \mathrm{C}, 45^{\circ} \mathrm{C}, 50^{\circ} \mathrm{C}$, $55^{\circ} \mathrm{C}$, and $60^{\circ} \mathrm{C}$ respectively until constant weights were obtained at three consecutive reading. The cooled dried slices were crushed and then milled (cyclone mill) into flour. The milled flour was sieved using a 75um (micron meter) to obtain fine flour of uniform particle size. The moisture, fat, crude fibre, protein, reducing sugars, ash, vitamin $\mathrm{C}$ and beta carotene contents of the orange flesh sweet potato flour was determined using American Association of Analytical Chemists (AOAC) [19].

The various milled samples were finally analysed for the nutritional properties using prescribed standard methods
[19]. The data generated were subjected to statistical analysis, using Statistical Package for Social Science (SPSS) Analysis of Variance (ANOVA) and Duncan's multivariate test was used to determine the level of significance of variables at different temperatures with reference to the control sample.

\section{RESULTS AND DISCUSSION}

The result showed that the nutritional composition of the fresh orange flesh sweet potato tubers (OFSPT) consists of $4.87 \%$ crude protein, $52.00 \%$ moisture content, $6.00 \%$ crude fibre, $2.15 \%$ ash, $3.6 \%$ fat, $64.58 \%$ carbohydrate, 123.0 $\mu \mathrm{g} / 100 \mathrm{~g}$ Vitamin $\mathrm{C}$ and $42.45 \mu \mathrm{g} / 100 \mathrm{~g}$ beta-carotene content. The nutritional properties such ash, protein, fibre, carbohydrate contents for fresh orange flesh sweet potato used for this study are similar to that of white Mexican sweet potato cultivar [13]. The beta-carotene content agrees with previous reports which vary between 29- $150 \mu \mathrm{g} / \mathrm{g}$ depending on the cultivar [13] [10]. The moisture content, crude fibre, ash and fat contents are higher than that are previously reported, this may be due to varietal differences and specie [15], [16]. The proximate and vitamin composition (nutritional properties) of orange flesh sweet potato flour as influenced by drying temperature are as presented in Table 1 and 2 respectively.

\section{Moisture content}

The moisture content value recorded for all drying temperature range between $40-60^{\circ} \mathrm{C}$ was $3.3-6.2 \%$. Statistical analysis showed that all the values obtained for different drying temperature are significantly different $(p<0.05)$. The moisture content value is within the range of 2.50\%-13.2\% reported for local white flesh (LWF) and local yellow flesh (LYF) sweet potato varieties respectively [14], [15]. A moisture content of $12.55 \%$ was considered to be the critical moisture content of flour within a locality that has ambient temperature range of $27-29^{\circ} \mathrm{C}$ while a value of $10 \%$ was recommended for long term storage [16], [17].

The moisture content of the OFSPF decreased with increase in drying temperature from $6.20 \%$ at $40^{\circ} \mathrm{C}$ to $3.3 \%$ at $60^{\circ} \mathrm{C}$. This trend is familiar since increase in temperature has direct effect in drying of the flour by lowering its MC. The continuous increase will lead to burning and ashing of the flour, while a decrease will lead to more moisture that will accelerate chemical and microbiological deterioration especially during storage [16], [17].

(i) Ash and fat contents

The ash and fat content were significantly $(p<0.05)$ affected by drying temperature, but presented a different trend. While the ash content decreased with increase in drying temperature, the fat content increases with the increase in drying temperature. Within the range of $40^{\circ} \mathrm{C}$ to $60^{\circ} \mathrm{C}$, the ash increased from $4.80 \%$ to $5.50 \%$ and fat from $1.03-1.83 \%$ as presented in Table.1. The increases in values are in agreement with previous work on sweet potato tubers dried at higher temperatures [5], [16]. The difference may be due to varietal difference, different temperature range, and pre- 
treatment process which were reported to affect the protein, ash and crude fibre contents of SPF [16], [14].

(i) Crude fibre and crude protein contents

The result of statistical analysis showed that increase in drying temperature affected the crude protein contents of orange flesh sweet potato flour significantly. With the increase of temperature from $40^{\circ} \mathrm{C}$ to $60{ }^{\circ} \mathrm{C}$, the crude protein content decreased with increase in temperature from $0.25 \%$ to $0.24 \%$, and the crude fibre and $3.03 \%$ to $1.75 \%$. Denaturation of protein at higher temperature values may be responsible since it was a progressive decrease. This result is in agreement with previous reports on the effects of pretreatments processes such as blanching, parboiling on the crude protein of SPF [17] [15] Statistical analysis showed that increase in drying temperature has no significant effect on the crude fibre.

(ii) Carbohydrate and reducing sugar content

The result of the carbohydrate values (CHO) and reducing sugar increased from $84.69 \%$ to $87.38 \%$ and total sugar value from $33.5 \%-48.00 \%$. These results are similar to that of previous work on other varieties of sweet potato which reported a range of $32-47 \%$ [16]. This showed SPF flour dried within the temperature range of $40^{\circ} \mathrm{C}$ to $60{ }^{\circ} \mathrm{C}$ will enhance energy in diet. It has been reported that carbohydrate with increases with increase in drying temperature with drying temperatures significantly affecting starch-related nutritional and functional properties [17] [18] [19]. Drying temperature is positively correlated with amylose content, resistant starch and viscoamylographic properties, mainly at temperatures higher than $40^{\circ} \mathrm{C}$ [18]. It has also been reported that the higher the drying temperature, the higher the reducing sugars content and the lower the starch content [16]. The difference recorded may be due to differences among the studied varieties and or experimental error. Temperature significantly influences the morphology of starch granules and so it is likely that other variable [16] [20]. The general result of this study showed, that most nutritive values of the major desired nutrients are still retained within the drying temperature range which a positive result for the intended process and product optimization.

(iii) Beta carotene content/vitamins content.

The result of the statistical analysis shows beta carotene content of the orange flesh sweet potato decreases progressively with increase in the drying temperature. It also reveals that between the drying temperature ranges of 40$60^{\circ} \mathrm{C}$, the beta carotene content decreased from 424 to $202 \mathrm{mg} / \mathrm{g}$. The result of the statistical analysis showed that drying temperature had significant $(p<0.05)$ effect on the beta carotene, Vitamin $\mathrm{C}$ and Vitamin A contents of orange flesh sweet potato flour. This may have been contributed by the volatility of the vitamins content especially at higher temperatures [16]. This implies that because of the importance of rich in vitamin A beta carotene, a choice of drying temperature should be such that the b-carotene content will still be in greater quantity considering its gains as the principal nutrient of OFSP [10]. To retain the bcarotene content, drying temperature should not be too high to harness the wonderful attributes of beta carotene in OFSP [12] [15]. The progressive decrease may be due to the fact that high temperature affects virtually all quality/ nutritional properties of food crops especially vitamins.

Table 2. Effect of drying temperature on the proximate properties of OFSP flour

\begin{tabular}{|c|c|c|c|c|c|c|c|c|c|c|c|c|c|c|}
\hline \multirow{2}{*}{$\begin{array}{l}\text { Temp } \\
\left({ }^{\circ} \mathrm{C}\right) \\
\text { Control }\end{array}$} & \multicolumn{2}{|c|}{ Carbohydrate (\%) } & \multirow{2}{*}{$\begin{array}{l}\text { Moisture } \\
(\%)\end{array}$} & \multirow{2}{*}{$\begin{array}{l}\text { content } \\
\pm 0.90^{\mathrm{a}}\end{array}$} & \multicolumn{2}{|c|}{ Ash (\%) } & \multicolumn{2}{|c|}{ Fat (\%) } & \multicolumn{2}{|c|}{ Crude fibre (\%) } & $\begin{array}{l}\text { Reducing } \\
\text { (mg/g) }\end{array}$ & sugar & \multicolumn{2}{|c|}{ Crude protein (\%) } \\
\hline & 64.58 & $\pm 1.12^{\mathrm{b}}$ & & & 2.15 & $\pm 0.11^{\mathrm{c}}$ & 3.60 & $\pm 0.19^{\mathrm{a}}$ & 6.00 & $\pm 0.31^{\mathrm{a}}$ & 30.20 & $\pm 0.52^{d}$ & 4.87 & $\pm 0.25^{\mathrm{a}}$ \\
\hline 40 & 84.69 & $\pm 1.96^{\mathrm{a}}$ & 6.20 & $\pm 0.14^{\mathrm{b}}$ & 4.80 & $\pm 0.28^{\mathrm{b}}$ & 1.03 & $\pm 0.06^{\mathrm{e}}$ & 0.25 & $\pm 0.01^{\mathrm{b}}$ & 33.55 & $\pm 0.77^{\mathrm{d}}$ & 3.03 & $\pm 0.17^{\mathrm{b}}$ \\
\hline 45 & 84.66 & $\pm 1.71^{\mathrm{a}}$ & 4.90 & $\pm 0.10^{c}$ & 5.20 & $\pm 0.15^{\mathrm{ab}}$ & 1.48 & $\pm 0.03^{\mathrm{d}}$ & 0.25 & $\pm 0.01^{\mathrm{b}}$ & 47.15 & $\pm 0.95^{\mathrm{b}}$ & 3.51 & $\pm 0.07^{\mathrm{b}}$ \\
\hline 50 & 84.90 & $\pm 2.45^{\mathrm{a}}$ & 4.50 & $\pm 0.13^{c}$ & 5.20 & $\pm 0.15^{\mathrm{ab}}$ & 1.52 & $\pm 0.10^{\mathrm{cd}}$ & 0.23 & $\pm 0.01^{\mathrm{b}}$ & 53.00 & $\pm 1.53^{\mathrm{a}}$ & 3.35 & $\pm 0.21^{\mathrm{b}}$ \\
\hline 55 & 85.42 & $\pm 3.45^{\mathrm{a}}$ & 4.80 & $\pm 0.19^{c}$ & 5.40 & $\pm 0.22^{\mathrm{a}}$ & 1.81 & $\pm 0.07^{\mathrm{bc}}$ & 0.18 & $\pm 0.01^{\mathrm{b}}$ & 41.50 & $\pm 1.68^{\mathrm{c}}$ & 2.39 & $\pm 0.10^{c}$ \\
\hline 60 & 87.38 & $\pm 1.01^{\mathrm{a}}$ & 3.30 & $\pm 0.04^{\mathrm{d}}$ & 5.50 & $\pm 0.10^{\mathrm{a}}$ & 1.83 & $\pm 0.03^{\mathrm{b}}$ & 0.24 & $\pm 0.00^{\mathrm{b}}$ & 48.60 & $\pm 0.56^{\mathrm{b}}$ & 1.75 & $\pm 0.03^{\mathrm{d}}$ \\
\hline
\end{tabular}

Mean on the same column with different superscripts are significantly different $(\mathrm{p} \leq 0.05)$

Table 2. Effect of drying temperature on the vitamin content of OFSP flour

\begin{tabular}{|c|c|c|c|c|c|c|}
\hline \multirow{2}{*}{$\frac{\text { Temp }\left({ }^{\circ} \mathrm{C}\right)}{\text { Control }}$} & \multicolumn{2}{|c|}{ Vitamin C (mg/g) } & \multicolumn{2}{|c|}{ Vitamin A (mg/g) } & \multicolumn{2}{|c|}{ Beta carotene (mg/g) } \\
\hline & 123.00 & $\pm 2.13^{\mathrm{a}}$ & 391.00 & $\pm 6.77^{\mathrm{a}}$ & 424.50 & $\pm 7.35^{\mathrm{a}}$ \\
\hline 40 & 109.00 & $\pm 2.52^{\mathrm{b}}$ & 268.20 & $\pm 6.19^{b}$ & 351.20 & $\pm 8.11^{\mathrm{b}}$ \\
\hline 45 & 101.00 & $\pm 0.58^{\mathrm{c}}$ & 289.80 & $\pm 5.86^{\mathrm{b}}$ & 301.70 & $\pm 6.10^{\mathrm{c}}$ \\
\hline 50 & 101.00 & $\pm 0.58^{c}$ & 268.30 & $\pm 7.75^{\mathrm{b}}$ & 280.80 & $\pm 8.11^{\mathrm{c}}$ \\
\hline 55 & 83.80 & $\pm 3.39^{d}$ & 240.90 & $\pm 9.74^{\mathrm{c}}$ & 225.60 & $\pm 9.12^{\mathrm{d}}$ \\
\hline 60 & 49.40 & $\pm 0.57^{\mathrm{e}}$ & 181.80 & $\pm 2.10^{\mathrm{d}}$ & 202.00 & $\pm 2.33^{\mathrm{e}}$ \\
\hline
\end{tabular}

Mean on the same column with different superscripts are significantly different $(\mathrm{p} \leq 0.05)$ 


\section{CONCLUSION}

It can be concluded that drying irrespective of the drying temperature significantly influence the moisture, fat, crude fiber, protein, vitamin $\mathrm{C}$ and beta carotene contents of fresh orange flesh sweet potato tubers while increase in drying temperature has no effect on the crude fiber. The drying temperature of $45^{\circ} \mathrm{C}$ is recommended for drying fresh orange flesh sweet potato tuber to obtain high quality flour in terms of lower MC (4.9\%) and higher protein (3.51\%), vitamin C (10.1 $\mathrm{mg} / 100 \mathrm{~g})$ and beta carotene (289.8 $\mathrm{mg} / 100 \mathrm{~g})$.

\section{REFRENCES}

[1] University of Washington, (UW) (2012).Evans School Policy Analysis and Research (EPAR): Nigeria Sweet Potato Value Chain. Retrieved from www. (EPAR) un Request 220 Nigerian sp valuechain.org. Retrieved on 8th July, 2017.

[2] Ugonna, C. U., Jolaossso, M.O., and Onwualu, A. P. (2013).A Technical Appraisal of Potato Value Chain in Nigeria. International Research Journal of Agricultural Science and Soil Sciences 39829 301.

[3] Ishida, H. (2000) Nutritive evaluation on chemical components of leaves, stalks, and stems of sweet potato (Ipomoea batatas). Food chemistry, 68:p 359-369.

[4] International Potato Centre (IPC). (1994). Sweet potato Situation and Priority Research in West and Central Africa. In L. H. Rancon, C. Martin, \& I. Zandstra (Eds.), Proceedings of the Workshop Held in Douala, Cameroon (p. 142). Lima, Peru: International Potato Centre (CIP).

[5] Bovell - Benjamin, A.C. (2007). Sweet Potato: A review of its past, present, and future role in human nutrition. Advance in Food Nutrition Research 52(1), 1 - 59.

[6] Woolfe, J.A., (1992). Sweet potato; An untapped Food Resource. Cambridge University Press, New York UK. pp 1-39.

[7] FAO. (2004). Statistical Yearbook. Rome: Food and Agriculture Organisation.

[8] Ssebuliba,J M., Nsubuga, E. N., Myonga, J. H., (2001). Potentials of orange and Yellow Flesh Sweet Potato Cultivar for Improving Vitamins A nutrition in Central Uganda. African Crop Journal of Science, Vol. 9 No.1 pp 309-316.

[9] Rodriguez - Amaya, D.B., Nutti, M.R., and Viana de Carvalho, J.L. (2011). Carotenoids of sweet potato, cassava, and maize and their use in bread and flour fortification. In preedy, V. R., Watson, R.R., and Patel, V.B. (Eds.). Flour and Breads and their Fortification in Health and Disease prevention P.301 - 311. London Academic Press.

[10] Mbwaga, z. (2007).Quality and Yield Stability of Orange Flesh Sweet Potato Varieties in Different Agro-Ecologies: A thesis Presented to The University of Zambia for Award of Msc. In Agronomy.

[11] Takahata, Y., Noda, T., Nagata, T.(1993).HPLC determination of beta carotene content of sweet potato cultivars and its relationship with colour values. Japanese J. Breed 43, 421-427.

[12] Trejor-Gonzalez, A. S., Loyo-Gonzalez, A. G.,and MungulaMazariegos, M. R. (2009). Evaluation of bread made from wheat sweet potato composite flour. International Food research Journal. 21, (14), 1683.

[13] Fessehaye, H. D, \& Rungarun, S (2017). Effect of drying temperature on functional and digestive properties of sweet potato flour. Proceedings of $63^{\text {rd }}$ IRES International conference Bangkok, 5- $6^{\text {th }}$ March 2017, 978-93-86291-88-2

[14] Bengtsson (2008). Effects of various traditional processing methods on the all-trans-b-carotene content of orange flesh sweet potato flour. Journal of food composition and analysis, 21: p 134-143.

[15] Nicanuru, C., Laswai, H. S.,Sila, D.N (2015). Effect of sun-drying on nutrient content of orange flesh sweet potato tubers in Tanzania. Sky Journal of Food Science, 4, (7), 091-101.

[16] Khanitta, R.M. Salvimon, C. Monthana, W. Norong, D. (2016). Effect of drying conditions on properties pigments and antioxidants activity of pre treated oranges and purple flesh sweet potatoes. 53, (4), 18111822.

[17] Olatunde, G.O. Henshaw, F. O.Idowu, M. Tomlins, K (2015). Quality Attributes of sweet potato flour as influenced by variety pretreatments and drying. Journal of Food Science and Nutrition, 1-13.
[18] AOAC (2005). Official methods of analysis $18^{\text {th }}$ ed. Arlington, V.A Association of Official Analytical Chemist PP. 806-842

[19] Akyildiz, A., Aksay, S., Benli, H., Kiroglu, F., and Fenercioglu, H. (2004). Determination of changes in some characteristics of persimmon during dehydration at different temperatures. Journal of Food Engineering, 65, 95-99.

[20] Correira, p. Antonio, L. Beroo-da-Costa, M.l.(2012). Effect of drying temperature on starch related function and thermal properties of chestnuts flour. Food and Byproducts processing, 90 (2), 284-294. 